\title{
MUSIK ODROT DI KABUPATEN PONOROGO
}

\author{
Hengki Triprasetyo ${ }^{1}$ \\ Institut Seni Indonesia Yogyakarta
}

\begin{abstract}
Odrot music is the art of music featured in Ponorogo, existing end centuries of Dutch colonialism in Indonesia, but its development was started in 1958. From then on stand several music groups Odrot, but that survive today are a group of music Odrot Kelana Ria. Although there are other groups who also manages Music Odrot, but the players invited players in Kelana group Ria. Music Odrot is a musical ensemble consisting of instruments trumpet, Euphonium 1, Euphonium 2, flugel, sousaphone (which by the player music Odrot called a piston, tenor 1, tenor 2, kaltu, bass), drums, kendang ciblon, ketipung dangdut, jidor and cer, keyboard and electric bass.

Odrot Music initially brought the songs of preaching Islamic nuance. Furthermore, Odrot music was developed in accordance with the times so that the songs were not limited to propaganda songs where tailored to the needs of supporters. This study aimed to describe a way of presenting Odrot music and explain its function in society in detail. Odrot Music ensemble distinguished by traditional and modern terms: so-called traditional because of the instruments used is a piston, tenor 1, tenor 2, kaltu, bass, drums, kendang ciblon, ketipung dangdut, jidor and cer; called modern because coupled with keyboard instruments and electric bass. If the ensemble Odrot Music brings the songs styles (langgam), the instruments which are used namely kendang ciblon, while dangdut songs accompanied by ketipung dangdut.

There is a basic song which (if not in special circumstances) is always played the name of that song is Ponoragan Kebo Giro. In addition, this song further characterize Odrot. Ponoragan songs Kebo Giro consists of 8 (eight) bars are played repeatedly in accordance with the cue trumpet. The song is sung to the rhythm of the Odrot's mars and traditional. Therefore, the ordot main function is as an entertainment in addition to other functions as an aesthetic presentation, the physical response, local cultural identity, informal educational facilities, media propaganda, cultural continuity, communication, and community integration.
\end{abstract}

Keywords: Odrot Music, Ponoragan, Kebo Giro, Society.

\begin{abstract}
Abstrak
Musik Odrot merupakan seni musik yang terdapat di kabupaten Ponorogo, yang sudah ada pada akhir penjajahan Belanda di Indonesia, namun perkembangannya dimulai sejak tahun 1958. Sejak itu berdirilah beberapa kelompok Musik Odrot, namun yang bertahan hingga kini adalak kelompok
\end{abstract}

\footnotetext{
${ }^{1}$ Mahasiswa Jurusan Etnomusikologi FSP ISI Yogyakarta.
} 
Musik Odrot Kelana Ria. Meskipun ada kelompok yang lain yang juga mengelola Musik Odrot, namun pemainnya mengundang pemain yang ada di kelompok Kelana Ria. Musik Odrot adalah sebuah ansambel musik yang terdiri dari instrumen terompet, euphonium 1, euphonium 2, flugel , sousaphone (yang oleh pemain Musik Odrot disebut dengan piston, tenor 1, tenor 2, kaltu, bass), tambur, kendang ciblon, ketipung dangdut, jidor dan cer, keyboard, dan bass elektrik.

Musik Odrot pada awalnya membawakan lagu-lagu dakwah yang bernafaskan Islam. Akan tetapi Musik Odrot pun berkembang sesuai dengan perkembangan zaman sehingga lagu-lagunya tidak terbatas pada lagu-lagu dakwah namun disesuaikan dengan kebutuhan masyarakat pendukungnya. Penelitian ini bertujuan untuk mendeskripsikan secara detail bentuk penyajian Musik Odrot serta menjelaskan fungsinya dalam masyarakat.Ansambel Musik Odrot dibedakan dengan istilah tradisional dan moderen: disebut tradisonal karena instrumen yang digunakan adalah piston, tenor 1 , tenor 2, kaltu, bass, tambur, kendang ciblon, ketipung dangdut, jidor dan cer; disebut moderen adalah karena ditambah dengan instrumen keyboard dan bass elektrik. Apabila ansambel Musik Odrot membawakan lagu-lagu langgam, maka instrumen ynga digunakan adalah kendang ciblon, sedangkan lagu-lagu dangdut diiringi dengan ketipung dangdut.

Ada sebuah lagu pokok yang (bilamana tidak dalam keadaan khusus) selalu dimainkan yaitu lagu Ponoragan Kebo Giro. Lagu ini selanjutnya menjadi ciri khas Musik Odrot. Lagu Ponoragan Kebo Giro terdiri dari 8 (delapan) birama yang dimainkan secara berulang-ulang sesuai dengan aba-aba terompet. Lagu ini dibawakan dengan irama mars dan dengan Musik Odrot tradisional. Fungsi utama Musik Odrot adalah sebagai hiburan di samping fungsi yang lain sebagai presentasi estetis, respon fisik, identitas budaya lokal, sarana pendidikan informal, media propaganda, kesinambungan budaya, sarana komunikasi, dan pengintegrasian masyarakat.

Kata Kunci : Musik Odrot, Ponoragan, Kebo Giro, Masyarakat.

\section{Pendahuluan}

Kesenian yang ada di Ponorogo lebih banyak hidup berdampingan dengan masyarakat Jawa yang pada umumnya yakni seni karawitan. Akan tetapi Ponorogo sendiri, ansambel gamelan Reyog sudah dapat dipakai untuk mengiringi gending-gending langgam maupun di buat campursari, terbukti pada pementasannya saat Reyog dalam format Reyog Obyog, lagu yang disajikan adalah lagu-lagu yang populer pada saat itu. Perkembangan musik gamelan Reyog lebih berkembang pesat karena hanya beberapa instrumen yang ada dalam 
ansambel tersebut, akan tetapi Musik Odrot juga berkembang di beberapa kecamatan daerah Ponorogo.

Musik Odrot sering ditampilkan dalam acara-acara hajatan, khitanan, dan malam seni selain itu juga ditampilkan pada hari besar kemerdekaan. Musik Odrot merupakan kesenian yang berbeda dari segi bentuk, cara memainkan dan cara penyajiannya serta menarik untuk disaksikan. Sebagai salah satu kebudayaaan yang ada di masyarakat desa Lengkong, Musik Odrot perlu dikembangkan dan dilestarikan sesuai dengan tingkat perkembangan musik moderen saat ini agar dapat diterima dan berkembang di tengah-tengah masyarakat.

Musik Odrot ini bermula dari dibawanya peralatan musik dari bangsa Belanda ke wilayah Ponorogo. Nama Musik Odrot itu sendiri diambil dari sumber suara (anamatopea) salah satu instrumen musik dari ansambel ini yakni shausophone atau bass dari wilayah musik tersebut. Apabila instrumen ini dimainkan akan menghasilkan bunyi "drot....ot....dro...t”, maka dari nama Odrot sendiri lahir dari bunyi instrumen tersebut namun awal berdirinya bukan berarti sudah mempunyai penamaan Musik Odrot, akan tetapi dengan penyebutan musik tiup saja.

Pencetus nama Odrot adalah Sri Sarno selaku kepala Departemen Pendidikan dan Kebudayaan kabupaten Ponorogo pada tahun 1979 diberikan kepada Haji Abdulloh pada acara lomba seni musik tiup di kabupaten Ponorogo dengan bertolak belakang dari nama Odrot di atas. Seni musik tiup grup Haji Abdulloh dari desa Lengkong kecamatan Sukorejo berhasil meraih juara pertama, dari sinilah nama Musik Odrot diberikan kepada grup tersebut. Pemberian nama itu telah disambut baik oleh Haji Abdulloh dan anggota grup Musik Odrot serta digunakan hingga saat ini.

1. Sejarah Musik Odrot Kabupaten Ponorogo

Masa penjajahan Belanda terhadap bangsa Indonesia berlangsung selama 350 tahun, maka dari sekian waktu penjajah Belanda banyak meninggalkan sejarah maupun peninggalan di wilayah Indonesia sampai saat ini. Dapat dilihat dari sekian bentuk instrumen Musik Odrot merupakan peningalan Belanda. Pada masa pemerintahan Belanda di Indonesia musik tiup ini digunakan sebagai 
penghormatan pemberangkatan angkatan perang Belanda. Selain itu, musik tiup yang berasal dari Belanda tersebut juga sebagai penghibur para pemimpin Belanda. Bahwa siapa rakyat Indonesia yang dapat memainkan musik boleh untuk tidak bekerja oleh penjajah Belanda namun bermain musik tiup dan beberapa musik lainnya untuk menghibur para penjajah Belanda.

Lahirnya musik tiup yang sekarang dikenal dengan nama Musik Odrot diperkirakan oleh pimpinan Musik Odrot berawal sama dengan datangnya tanjidor namun lebih dikenal di daerah Ibukota dikarenakan pusat dari perlintasan antar negara berpusat di daerah Jakarta. Kemudian dengan perluasan Belanda menjajah Indonesia, alat musik tersebut melebar hingga ke beberapa daerah termasuk Ponorogo dan terbentuklah ansambel tersebut dengan nama Odrot, bukan lagi tanjidor.

Peninggalan alat tanjidor yang ada Alat-alat musik tanjidor diantaranya adalah Bedug (Bas Drum), Tambur (Snare drum), Simbal, Klarinet, Thrombon, Piston (Terompet), Tenor, Bass Throm. Diantara instrumen-instrumen tersebut hanya klarinet dan thrombon yang tidak ada dalam ansambel Musik Odrot Ponorogo. Peralatan tanjidor yang ada sekarang merupakan peninggalan Belanda sehingga usianya sudah sangat tua. Dengan alat-alat musik setua itu, tanjidor biasa digunakan untuk mengiring acara hajatan dan arak-arakan pengantin. Sama halnya dengan Musik Odrot Kelana Ria dari dibelinya sekitar tahun 1958 dan itu pun dalam keadaan bekas, sampai saat ini instrumen Musik Odrot belum ada pergantian walaupun sudah saatnya diganti dengan yang baru dan terlihat sangat tua.

Musik Odrot pada mulannya berciri khas mensajikan lagu-lagu shalawat, namun salah satu ciri khas tanjidor adalah membawakan lagu-lagu Betawi dan dapat disebut cerminan adaptasi masyarakat lokal terhadap musik barat. Diantara lagu-lagu lain yang sering dibawakan oleh orkes tanjidor, antara lain Kramton, Bananas, Cente Manis, Keramat Karam (Kramat Karem), Merpati Putih, Surilang, dan lain-lain. Lagu Keramat Karam lahir karena peristiwa meletusnya Gunung Krakatau yang menelan banyak korban. Lagu-lagu tersebut dimainkan atas dasar keinginan masyarakat kota Betawi yang pada tahun 1920-an sangat digemari dan 
dianggap 'lagu baru' pada masa itu. Adapun Lagu Kramton dan Bananas adalah lagu Belanda berirama mars. Begitu juga pada Musik Odrot irama mars dan juga lagu-lagu mars disajikan sedemikian rupa dengan suasana semangat layaknya mengiringi barisan pasukan perang.

Musik tersebut dimiliki masyarakat Ponorogo karena hadiah dari pemerintah Belanda dalam rangka lomba sholawatan yang diadakan di Surakarta. Kebetulan lomba tesebut dimenangkan peserta dari kecamatan Jetis kabupaten Ponorogo. Akhirnya mulai diusahakan untuk tujuan lainnya dan tak dapat dipungkiri karena pemulanya orang-orang yang agamis yaitu Islam maka sampai saat ini pemain serta peminatnya berasal dari masyarakat Islam (Subiastuti, 1996).

Keberadan seni Musik Odrot di Jetis, selanjutnya menginspirasi daerah kecamatan lain seperti kecamatan Balong, Sawoo, Sampung, Jambon, Siman, Pulung, dan beberapa tempat lainya. Namun dari 11 grup yang terdapat di Ponorogo, sampai saat ini masih ada dua Musik Odrot yang masih berjalan. Diantarannya adalah Musik Odrot pondok pesantren moderen Darussalam gontor dan Musik Odrot Kelana Ria desa Lengkong kecamatan Sukorejo. Kurang eksisnya dari 9 grup lainnya dikarenakan regenerasi yang kurang diperhatikan dan juga kurangnya pementasan dan job dari sekian grup tersebut, maka sebagian dari alat-alat grup tersebut dijual ke grup lain maupun tetap disimpan tanpa dimainkan. Dapat dikarenakan kebanyakan dari mereka menyerah dahulu sebelum belajar dengan serius menekuni alat musik tiup tersebut.

Musik Odrot Kelana Ria desa Lengkong lahir sejak tahun 1958 dengan penyebutan musik tiup saja sebelum dikenal dengan nama Musik Odrot hingga saat ini. Kesenangan haji Abdulloh terhadap seni Musik Odrot mendorong keinginannya untuk membeli beberapa instrumen Musik Odrot tersebut, meski pembeliannya dilakukan secara swadaya bersama tujuh saudara kandungnya, instrumen tersebut dibeli dari daerah desa Gamping kecamatan Sawoo. Pembelian tersebut dimaksudkan untuk kepentingan media hiburan. Hal ini mengingat kebiasan di wilayah Ponorogo apabila mempunyai hajat seperti resepsi pernikahan, khitanan, bersih desa dan sebagainnya memerlukan hiburan dan wilayah daerah kecamatan Sukorejo biasa mengundang Musik Odrot guna 
menghibur masyarakat yang datang dibeberapa acara tersebut. Atas motivasi tersebut, akhirnya pak Haji Abdulloh membeli seperangkat Musik Odrot.

Sebelum diberi nama grup "Kelana Ria" oleh Abdul Jalil yang sekarang sebagai pemain sekaligus ketua grup Musik Odrot Kelana Ria, awal berdirinya diberi nama "Tirta Kencana". Para pemain Musik Odrot grup ini pada awal berdirinya berasal dari keluarga dekat Haji Abdulloh dan juga beberapa pemilik dari instrumen yang telah dibeli. Kemudian diajarkan kepada siapa saja di sekitar wilayah desa Lengkong tersebut terutama yang berminat untuk mempelajari Musik Odrot. Kesenangan dan sebagai hiburan di tempat sekitarnya, lambat laun kesenian ini menjadi suatu pertunjukkan yang diminati oleh masyarakat dengan sebutan "ditanggap" dalam acara resepsi pernikahan, Nadzar, Khitanan, malam seni, Bersih desa, hari ulang tahun kabupaten Ponorogo, Grebeg Suro, delegasi budaya dan sebagainya.

Pada tahun 1980 nama "Tirta Kencana" diganti dengan nama "Kelana Ria" oleh Abdul Jalil selaku pimpinan Musik Odrot. Pergantian nama tersebut didasari dengan arti dan harapan proses perjalanan Musik Odrot pada selanjutnya. Kelana berarti berkelana dan Ria berarti senang. Secara keseluruhan berarti berkelana mencari kesenangan dalam arti lain adalah musik tersebut akan terus lestari berkelana kesana kemari menghibur dan juga tanggapan dalam media mereka untuk berkelana. Alasan perubahan nama dikaitkan dengan visi dan misi kelompok yang berorientasi pada profesi, sedangkan nama yang lama tidak ada kaitannya dengan misi pekerjaan yang dilakukan para seniman Musik Odrot grup tersebut.

Lagu yang disajikan pada awal terbentuknya Musik Odrot Kelana Ria adalah lagu-lagu shalawat, hal itu dipengaruhi dari keagamisan para pemain dan juga lingkungan pondok pesantren di desa Lengkong. Lambat laun masyarakat pun menuntut agar Musik Odrot menyajikan lagu-lagu sesuai selera penonton dan penanggap. Sekarang lagu-lagu yang disajikan pada saat pentas bervariasi mulai dari langgam, qasidah, dangdut, dan juga pop namun tidak meninggalkan lagulagu yang bernafaskan Islam. Lain halnya itu ada satu lagu yang selalu di sajikan dalam setiap pementasan, yaitu Ponoragan Kebo Giro. Lagu tersebut yang 
menjadikan penting di pementasan Musik Odrot Kelana Ria. Karena saat lagu tersebut, Musik Odrot tidak memakai penambahan alat musik lain misalnya ketipung dangdut, kendang ciblon atau batangan, keyboard dan juga bass.

Musik Odrot sudah dikenal masyarakat sekitar luar daerah Ponorogo itu sendiri. Terbukti dengan banyaknya tanggapan yang sering dilaksanakan oleh grup Musik Odrot ini. Seperti halnya upacara 17 agustus di kabupaten Madiun, acara senada seirama di Taman Sedudo Nganjuk, acara Taman Bineka Tunggal Ika TVRI Surabaya, rekaman RRI Madiun, Nirwana Record, acara penyambutan tamu menteri, acara tahunan Grebeg Suro, ulang tahun kabupaten Ponorogo, Festival Seni Surabaya, delegasi budaya di Banyuwangi, dan beberapa acara lainnya. Namun dari pada itu semua, acara hajatan pernikahanlah yang paling sering pentas akan tetapi pada umumnya masa dimana pernikahan masyarakat Jawa yakni bulan Idul Fitri, Idul Adha, dan juga Sapar.

Pementasan Musik Odrot tidak hanya duduk disatu tempat saja atau dipanggung, namun dapat juga seacara arak-arakan. Setiap Grebeg Suro dan juga hari ulang tahun Ponorogo, Musik Odrot ikut arak-arakan berjalan dari kota lama Ponorogo menuju kantor kabupaten Ponorogo akan tetapi setelah sesampainya didepan kabupaten, Musik Odrot disediakan panggung untuk pentas sekian waktu dipanggung tersebut. Selaku pimpinan Musik Odrot, Abdul Jalil sebelumnya memberi pilihan kepada penanggap meminta Musik Odrot tradisional atau moderen. Perbedaan hanya pada Musik Odrot secara moderen yakni penambahan alat musik keyboard, ketipung dangdut, bass dan kadang kendang ciblon atau batangan pada karawitan guna untuk memainkan lagu-lagu langgam Jawa. Musik Odrot yang bermain secara tradisional yakni tidak ada penambahan alat musik di luar ansambel tersebut, namun lagu-lagu apa saja tetap dapat disajikan melalui dua bentuk penyajian tersebut.

\section{Analisis Musikologis Musik Odrot}

Tangga nada adalah rangkaian nada yang diawali dari tujuh buah nada pokok yakni Bb-C-D-Eb-F-G-A-Bb' yang disusun sesuai dengan tingkat 
ketinggian masing-masing nada. Susunan tujuh buah nada yang diakhiri oleh nada atau nada kedelapan disebut oktaf dari sebuah tangga nada. Fungsi tangga nada dalam sebuah permainan musik adalah sebagai dasar atau titik awal dan titik akhir. Oleh karena itu dalam memainkan instrumen musik apapun selalu berpijak pada tangga nada yang digunakan. Tangga nada yang digunakan instrumen trompet sebagai instrumen yang berperan menjadi melodi utama dalam Musik Odrot adalah sebagai berikut :

Contoh untuk 1 oktaf trompet $\mathrm{Bb}=\mathrm{Do}$

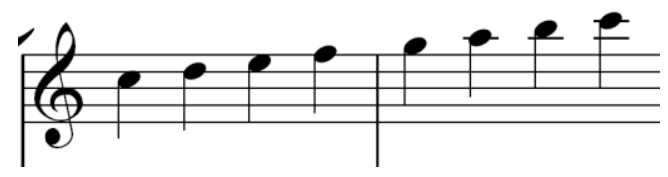

Nada : Bb C D Eb F G A Bb'

Secara umum tangga nada yang digunakan pada penyajian Musik Odrot adalah tangga nada diatonis. Penggunaan tangga nada diatonis dalam penyajian Musik Odrot akan lebih spesifik tergantung dari lagu yang dimainkan.

\section{Kajian Instrumen Musik Odrot}

Musik Odrot memiliki instrumen baku yang utuh menjadi alat musik pokok yang dimainkan diantaraya Trompet, Sousaphone, Euphonium, Tambur/Snare drum, Jedor dan Cer. Ansambel atau medium gabungan adalah dua atau lebih permainan yang terlibat dalam memainkan sebuah karya musik, dengan menggunakan lebih dari dua instrumen (Miller, tt: 87). Musik Odrot tergolong musik ansambel karena juga menggunakan lebih dari dua alat musik dalam penyajiannya. Musik Odrot yang digunakan untuk mengiringi arak-arakan umumnya alat musik yang memainkan melodi (Trompet) berada di barisan paling depan sedangkan Jedor paling belakang. Jika Musik Odrot dimainkan untuk hajatan tidak ada aturan untuk penempatan masing-masing alat musik hanya saja pada saat penyajian secara modern, pemain Trompet berdampingan dengan pemain Keyboard guna berkomunikasi mana kala akan memainkan lagu apa lebih dekat dan para pemain disediakan tempat duduk masing-masing. 
Musik Odrot desa Lengkong kecamatan Sukorejo memiliki jenis musik yang disajikan berbeda dengan Musik Odrot pada awalnya ada sampai sekarang ini. Pemain Musik Odrot membedakan Musik Odrot dalam penyajiannya menjadi dua yaitu Musik Odrot Tradisional dan Musik Odrot Modern. Musik Odrot disajikan secara utuh dengan ditambah vokal sehingga dalam sajinnya tidak lagi membawakan lagu-lagu instrumental seperti dalam sajian Musik Odrot secara utuh. Akan tetapi penyajian pada lagu-lagu berirama mars tetap instrumental tanpa adanya vokal

\section{Instrumen Musik Odrot Tradisional}

Pementasan Musik Odrot secara tradisional dimaksudkan tidak adanya penambahan musik lain di luar musik aslinya. Hanya saja menggunakan ketipung dangdut pada lagu-lagu selain irama mars, dan kendang ciblon pada lagu-lagu langgamn. Musik Odrot sebagian besar menggunakan instrumen musik tiup logam tersebut yakni diantaranya yang termasuk dalam keluarga ini adalah.Instrumen musik tiup logam berkatup, jenis instrumen musik ini menggunakan seperangkat katup (umumnya tiga atau empat, namun kadang-kadang ditemukan pula hingga tujuh atau lebih dalam beberapa kasus) yang dimainkan dengan menggunakan jari tangan. Musik Odrot Tradisional yang dipakai diantaranya adalah terompet, euphonium, sousaphone, tambur, jedor dan cer.

\section{Instrumen Musik Odrot modern}

Musik Odrot membagi menjadi dua jenis konsep pertunjukkan, dimana disesuaikan permintaan dari yang mengundang atau pihak penanggap. perbedaan yang terlihat adalah penambahan alat musik keyboard, gitar bass, ketipung dangdut dan kendang ciblon atau batangan. Penambahan tersebut dikatakan Abdul Jalil menuruti selera pasar yang ada dan juga memberi kesan penuh atau rapat disetiap bunyi yang dihasilkan. Selain dari itu, penambahan instrumen tersebut memberi kemudahan pemain Musik Odrot pada saat memenuhi permintaan lagu dari penonton. Karena dengan durasi pementasan yang sekian 
lama pemain trompet kadang merasa lelah apabila semua lagu dikuasai melodinya oleh trompet.

Bentuk penyajian Musik Odrot secara modern merupakan kolaborasi antara Musik Odrot sendiri dengan Musik electone yang cukup digemari masyarakat Ponorogo. Maraknya permintaan pasar atas pertunjukkan musik electone merupakan indikator yang menandakan musik tersebut digemari oleh masyarakat, sehingga Musik Odrot electone muncul menawarkan bentuk penyajian semam ini. Electone sendiri merupakan ansambel dengan instrumen minimalis, diantaranya keyboard sebagai pengiring utama, ketipung dangdut sebagai pembawa ritme dan juga Bass elektrik yang mempertebal ritme lagu. Bahkan di beberapa pertunjukkan hanya keyboard dan ketipung dangdut saja sebagai pengiring penyanyi dalam membawakan lagu. Instrumen electone dikategorikan dalam alat musik electrophone, ditinjau dari alat musik yang dimainkan. Adapun jenis instrumen Musik Odrot Modern sebagai berikut :

\section{Analisis lagu ponoragan kebo giro}

Menjelaskan atau mendeskripsikan bentuk musik diperlukan dua cara pendekatan. Kedua cara pendekatan tersebut pada dasarnya sangat berguna dan dianggap penting yaitu menganalisis dan mendeskripsikan apa yang didengar kemudian mendeskripsikan apa yang lihat (Nettl, 1964: 98). Kemudian Charles Seeger juga menawarkan dua pendekatan untuk menganalisis yaitu pendekatan preskriptif dan deskriptif. Pendekatan preskriptif merupakan pendekatan yang menuliskan bagian-bagian yang menonjol dalam musik saja. Sedangkan deskriptif adalah mentranskripsikan dengan menuliskan secara detail atau kata-kata (Nettl, 1964: 99). Hal ini menunjukan bahwa analisis musikal memang hal yang sangat penting.

Musik Odrot dapat memainkan lagu-lagu yang disajikan dengan tidak harus melihat notasi, hal ini dikarenakan para pemain belajar melalui pendengaran lisan namun tidak berarti tidak bisa membaca notasi. Akan tetapi dalam kenyataanya hanya beberapa pemain saja yang dapat membaca notasi dan notasi yang biasa mereka baca yakni notasi angka dan tidak mewajibkan semua pemain 
Musik Odrot harus bisa membaca notasi, sehingga sebagian dari pemain Musik Odrot memahami secara otodidak tanpa notasi. Transkripsi penotasian Musik Odrot ini menggunakan kedua pendekatan tersebut. Pendekatan preskriptif digunakan karena tidak semua dituliskan dalam bentuk notasi melainkan bagianbagian yang dirasa penting dan dianggap baku. Sementara pendekatan deskriptif dipergunakan karena dalam penjelasan transkrip menggunakan penjelasan secara detail dengan kata-kata.

Untuk menganalisis musik maka diperlukan simbol-simbol untuk menggambarkan bunyi yang didengar. Simbo-simbol yang berwujud angka, huruf maupun gambar inilah yang disebut dengan notasi. Untuk menganalisa Musik Odrot ini digunakan dua macam notasi yaitu not balok dan notasi angka. Notasi balok digunakan untuk menganalisis musik perkusi sementara notasi angka untuk menganalisis musik instrumental.

Analisis lagu ini menggunakan teknik transkripsi preskriftif, dengan menuliskan beberapa pokok-pokok lagu yang ada dalam lagu pokok Musik Odrot. Musik Odrot memiliki lagu pokok yang selalu dimainkan saat pementesan, yaitu Ponoragan Kebo Giro. Lagu tersebut dimainkan pada saat pembukaan dan juga penutupan saat Musik Odrot di pentaskan. Irama mars sebagai penggungah semangat menghiasi lagu tersebut dengan sedemikian rupa. Irama mars dalam Musik Odrot dimainkan secara instrumental. Kemudian permainan instrumen trompet lebih dominan dikarenakan volume suara yang dihasilkan cukup besar. Peranan instrumen Musik Odrot lainya seperti : Jedor, Euphonium, Tambur/snare drum, Cer, dan Sousaphone adalah memainkan motif isian permainannya masingmasing untuk mendukung alur melodi yang dimainkan oleh instrumen melodis terompet.

Lagu Ponoragan Kebo Giro memiliki unsur melodi yang memberikan kesan rasa, sedangkan ritmenya memberikan kesan fungsional penggugah semangat sesuai suasana yang diberikan dalam lagu tersebut. Pengatur ritme dalam Musik Odrot adalah snare. Pola tabuhan snare disesuaikan dengan lagu dan bertempo sedang atau moderato. Motif ritmis yang digunakan adalah triol besar. 
Introduksi dibunyikan oleh instrumen trompet sebagai instrumen dominan, namun dua ketuk hitungan awal saja kemudian disusul dengan instrumen yang lainnya. Dengan menggabungkan beberapa instrumen yang berbeda dapat memberi rasa dan kesan ketebalan lagu, sebab warna suara setiap instrumen yang berbeda-beda memberi kesan yang baik dalam menghidupkan suasana meskipun lagu tersebut tidak menggunakan vokal yang menyanyikan syair. Berikut ini adalah lagu pokok Ponoragan Kebo Giro memakai instrumen trompet sebagai melodi utamanya menggunakan notasi angka :

\section{Ponoragan Kebo Giro}

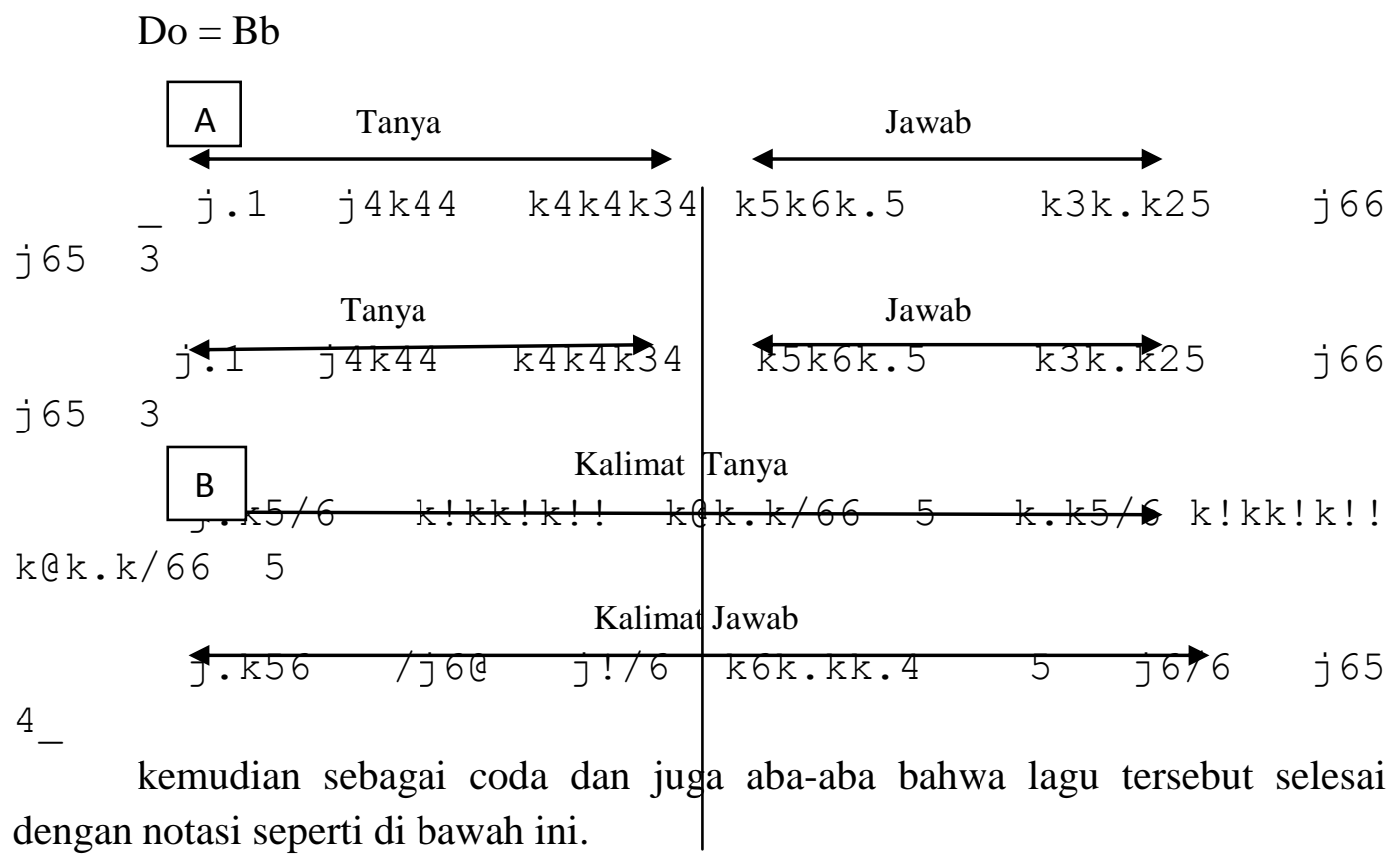
dengan notasi seperti di bawah ini.

j67!

\begin{tabular}{|c|}
\hline B \\
\hline
\end{tabular}

\section{Keterangan:}

1. Birama 1 dan 3 : motif tanya

2. Birama 2 dan 4: motif jawab

3. Birama 5 - 6 : kalimat tanya

4. Birama 7-8 : kalimat jawab 
\begin{tabular}{l|c|l} 
5. & A & merupakan bagian lagu pertama \\
6. & & merupakan bagian lagu kedua \\
\hline \hline B &
\end{tabular}

7. B' merupakan coda dan aba-aba lagu sebagai penanda lagu akan berhenti

Adapun isian transkripsi instrumen lainnya seperti berikut

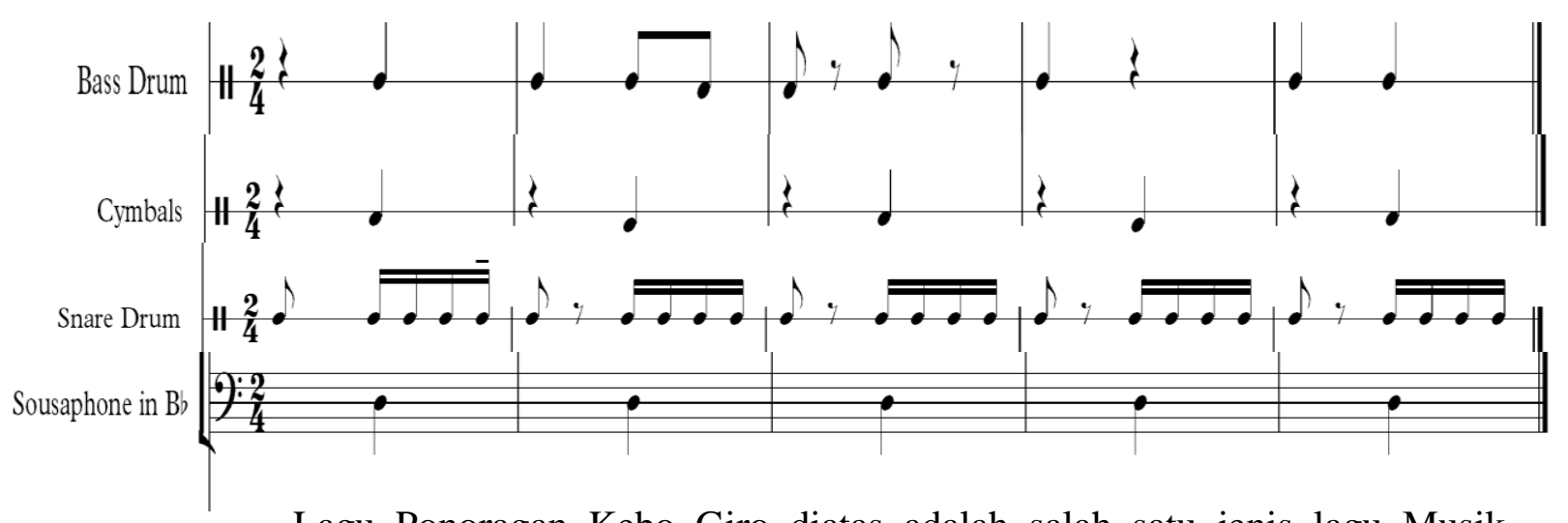

Lagu Ponoragan Kebo Giro diatas adalah salah satu jenis lagu Musik

Odrot sekaligus menjadi lagu pokok, terdiri dari dua bagian yaitu bagian A dan

Bagian B dan memiliki 8 birama. Bagian A terdiri dari birama 1 sampai birama 4, sedangkan bagian B terdiri dari birama 5 sampai birama 8. Berikut adalah hasil analisis dari lagu Ponoragan kebo Giro.

1) Kalimat Lagu

Kalimat lagu merupakan satu kesatuan musik yang tersusun dengan memakai bermacam-macam bentuk lagu atau bait. Biasanya sebuah kalimat lagu terdiri dari sebuah kalimat tanya atau antisiden dan sebuah kalimat jawab atau konsekuen. Dalam lagu Ponoragan Kebo Giro terdapat beberapa kalimat tanya dan jawab, adapun pembagianya adalah; bagian A birama 1 dan 3 merupakan farse tanya sedangkan biarama 2 dan 4 merupakan frase jawaban; bagian B terdiri dari birama 5 sampai 6 merupakan kalimat tanya, sedangkan birama 7 sampai 8 merupakan kalimat jawab.

Nada merupakan unsur terkecil dari musik, namun satu nada belum merupakan musik, oleh karena itu analisis berpangkal pada kelompok nada yang merupakan satu kesatuan dan inilah yang disebut motif. Motif merupakan sepotongan lagu yang merupakan satu kesatuan dan memiliki arti dalam dirinya 
sendiri (Prier, 1985: 26). Dalam lagu Ponoragan Kebo Giro terdapat motif pokok melodi yaitu birama satu pada hitungan satu sampai dengan birama dua pada hitungan ke empat, sedangkan yang lain merupakan pengembangan dari motif tersebut.

Terlihat bahwa ciri khas dari lagu tersebut terdapat pada motif dua birama pertama, kemudian terjadi pengembangan sampai dengan birama terakhir dan diulang dengan mengkondisikan keadaan yang ada.

$$
\begin{aligned}
& \mathrm{Do}=\mathrm{Bb}
\end{aligned}
$$

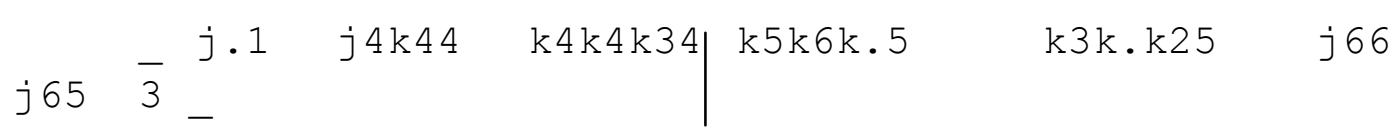

\section{Alur Komposisi lagu Ponoragan Kebo Giro}

Lagu Ponoragan Kebo Giro menjadi sebuah lagu pokok Musik Odrot dengan pengolahan bentuk kalimat yang terjadi adalah A A B' diulang tiga kali namun bagian $\mathrm{B}$ terakhir diulang pada satu birama pertama kemudian birama kedua berubah sebagai penanda berhentinya lagu tersebut. Satu putaran pertama (Bagian A) dan kedua memainkan motif yang sama. Berikutnya masuk pada bagian B dimana terdapat kalimat tanya yang terdapat dalam birama ke lima dan enam. Masuk birama ketujuh sampai delapan merupakan kalimat jawab dari bagian B birama kelima dan enam.

Lagu Ponoragan Kebo Giro dapat diulang beberapa kali namun dalam prakteknya minimal mengulang lagu tersebut sebanyak tiga kali saja, tetapi tidak menutup kemungkinan untuk diulang sekian kali. Lagu tersebut dapat berjalan sekian pengulangan tergantung pemain trompet kapan menghentikan lagu tersebut dalam coda yang telah disepakati. Terjadi maupun tidaknya pengulangan, pada dasarnya mengkondisikan suasana yang terjadi pada saat pementasan tersebut mengiringi sesuatu prosesi, atau hanya pembuka dan penutup pertunjukkan saja.

\section{Penutup}


Musik Odrot adalah salah satu bentuk kesenian musik yang ada di kabupaten Ponorogo. Musik tersebut dapat dihadirkan dalam berbagai acara baik formal maupun non formal. Peran tersebut menjadikan pentingnya Musik Odrot untuk dijaga keberadanya dan perlunya regenerisasi guna berlangsungnya ke masa yang akan datang. Perlunya kreativitas dalam perkembangannya adalah hal yang utama bagi musik Tersebut guna masyarakat penikmatnya mendapatkan hal yang bisa dirasakan baik melalui kreativitas musik yang disajikan. Keakraban masyarakat sekitarnya menimbulkan kesan positif bahwa peranannya dalam menghibur masyarakat menacapai sesuai tujuan dari adanya Musik Odrot. Selain dari berdakwah melalui lagu-lagu islami pada awal terbentuknya.

Terdapat dua aspek yang dapat dilihat, yakni aspek musikal yang menjelaskan tentang kajian teks dan aspek non musikal yang menjelaskan bagaimana aspek yang penting diperhatikan selain musik yang disajikannya dalam setiap pertunjukan Musik Odrot. Ansambel Musik Odrot dibedakan dengan istilah tradisional dan moderen: disebut tradisonal karena instrumen yang digunakan adalah piston, tenor 1 , tenor 2, kaltu, bass), tambur, kendang ciblon, ketipung dangdut, jidor dan cer; disebut moderen adalah karena ditambah dengan instrumen keyboard dan bass elektrik. Apabila ansambel Musik Odrot membawakan lagu-lagu langgam, maka instrumen ynga digunakan adalah kendang ciblon, sedangkan lagu-lagu dangdut diiringi dengan ketipung dangdut.

Ada sebuah lagu pokok yang (bilamana tidak dalam keadaan khusus) selalu dimainkan yaitu lagu Ponoragan Kebo Giro. Lagu ini selanjutnya menjadi ciri khas Musik Odrot. Lagu Ponoragan Kebo Giro terdiri dari 8 (delapan) birama yang dimainkan secara berulang-ulang sesuai dengan aba-aba terompet. Lagu ini dibawakan dengan irama mars dan dengan Musik Odrot tradisional. Lagu tersebut menjadi penyemangat dengan iramanya yang sedemikian rupa, terutama dapat dirasakan dari para pemain Musik Odrot sendiri.

Keberadaanya memiliki beberapa sendiri yakni fungsi utama Musik Odrot adalah sebagai hiburan di samping fungsi yang lain sebagai presentasi estetis, respon fisik, identitas budaya lokal, sarana pendidikan informal, media propaganda, kesinambungan budaya, sarana komunikasi, dan pengintegrasian 
masyarakat. Fungsi-fungsi tersebut memberikan penunjuk bahwa Musik Odrot masih dibutuhkan dalam pelestariannya melalui kegiatan yang menghadirkan Musik Odrot.

\section{Daftar Pustaka}

Djelantik, A.A.M. 1999. Estetika Sebuah Pengantar. Bandung: MSPI.

Kayam, Umar. 1981. Seni, Tradisi, Masyarakat. Jakarta: Sinar Harapan

Merriam, Alan. P. 1964. The Anthropology of Music. Chicago: Northwestern University Press.

Midgley, Rurth. 1976. Musical Instrument of The World. New York: Fact ob File Publiations.

Miller, Hugh M. terj. Triyono Bramantyo. t.t. Pengantar Apresiasi Musik Yogyakarta.

Mulyana, Deddy. 2012. Ilmu Komunikasi Suatu Pengantar. Bandung: PT Remaja Rosdakarya.

Nakagawa, Shin. 1999. Musik dan Kosmos: Sebuah Pengantar Etnomusikologi. Jakarta:Yayasan Obor Indonesia.

Nettl, Bruno. 1964. Theory and Methods in Etnomusicology. London: The Free Press of Glencoe Collier-Macmillan Limited.

Prier, Karl Edmun SJ. 1985. Ilmu Bentuk Analisa. Yogyakarta: Pusat Musik Liturgi.

Simanungkalit, Nortier (2008). Teknik Vokal Paduan Suara. Gramedia Pustaka Utama.

Smith. Jacqueline Smith.1985. Komposisi Tari Sebuah Petunjuk Praktis bagi Guru" terj. Ben Suharto. Yogyakarta: IKAPI.

Soeharso. 2011. Kamus Besar Bahasa Indonesia. Semarang:Widya Karya.

Utami, Munandar S C. (2002). Kreatifitas dan Keberbakatan "Strategi Mewujudkan Potensi Kreatif Dan Bakat". Jakarta:Gramedia Pustaka Utama. 